\title{
Методичний підхід до формування територіальної структури регіонального господарювання
}

Виявлено проблеми, пов'язані з впровадженням територіальної реформи. Розглянуто існуючі методичні підходи до формування оптимальної територіальної структури регіонального господарювання. Обтрунтовано доцільність використання кластерного аналізу у побудові оптимальної структури регіонального господарства. Відзначено важність використання відстані між територіальними об'єктами як основного критерію територіальної кластеризацї̈, щңо відображає інтереси населення, пов'язані з більщою доступністю до публічних освітніх, медичних та інцих видів послуг.

Виконано групування населених пунктів матриці відстаней методом $k$-середніх як найбільш популярного різновиду кластерного аналізу, який полягає в розділенні спостережень на окремі кластери за принципом близькості до центру, належсить до неісрархічних алгоритмів кластеризації та являє собою ітераційну процедуру.

Ключові слова: територіальна структура, формування, підходи, кластерний аналіз, критерій територіальної кластеризації, метод $k$-середніх.

\section{Вступ}

На сьогоднішній день ситуація 3 об'єднанням населених пунктів у нові територіальні структури - громади доходить до критичної точки. Для проведення анонсованих восени 2020 року виборів в органи місцевого самоврядування головною передумовою повинно стати завершення територіальної реформи. Незважаючи на наявність Перспективних планів об'єднання територій, розроблених на обласному рівні і затверджених КМУ [1], формування відбувається досить повільно. Статистичні дані вказують на низький рівень активності в даному питанні в окремих областях. Зокрема, у Донецькій області створено лише 13 об'єднаних територіальних громад (далі ОТГ), що займають лише $19,74 \%$ від загальної площі та складають 5\% чисельності населення [2].

Головною причиною ситуації, що склалася, є: по-перше, конфлікт інтересів серед населення міських, селищних та сільських рад; по-друге, незацікавленість окремих органів місцевої влади у формуванні ОТГ за тими принципами, що пропонує держава. Справа у тому, що на державному рівні активно впроваджується підхід до формування ОТГ, згідно з яким сільські ради повинні приєднатися до міських або селищних. Іншими словами центром громади може бути лише місто чи селище. Вказаний підхід простежується у раніше вказаних Перспективних планах об’єднання територій, які, на думку Міністерства розвитку громад і територій, грунтуються на чітких економічних, територіальних, демографічних розрахунках та пропонують формати найбільш спроможних територіальних громад [3]. Проте, районні органи влади та окремі представники місцевого бізнесу так не вважають та паралельно проводять зустрічі с активними представниками громадськості щодо формування однієї чи декількох ОТГ у межах свого району, що відкладає процес формування територіальної структури регіонального господарювання на невизначений час. Територіальна реформа триває більше п'яти років. Процес добровільного об'єднання не дав дієвих результатів. Настав час другого етапу системного об'єднання територій, що стає обов'язковим. Але питання потребує консенсусу.

Таким чином створення ОТГ стає неможливим без урахувань інтересів місцевого населення. У зв'язку 3 цим виникає необхідність вибору дієвого методичного підходу до формування оптимальної територіальної структури регіонального господарювання, в рамках якого буде забезпечуватися узгодження інтересів сторін.

\section{Аналіз останніх досліджень i публікацій \\ Досліджуванню методичних підходів} до формування територіальних структур присвячені роботи, як вітчизняних, так зарубіжних авторів, зокрема таких як Л. Хомюк, О. Тимошенко, В. Василенко, І. Баб'юк, О.Чепель, Р. Савенко, I. Скрильник, В. Кутьїн та ін. Слід зауважити, що різні точки зору, 
представлені в цих роботах, не вирішують проблему в силу того, ще існує єдиного методичного підходу до формування оптимальної територіальної структури регіонального господарювання. Таким чином дана проблема вимагає більш системного вивчення.

\section{Мета статті}

На основі аналізу існуючих підходів обгрунтувати метод та критерії формування оптимальної територіальної структури регіонального господарювання.

\section{Методи дослідження}

Метод k-середніх, який $є$ одним iз найбільш популярних різновидів кластерного аналізу.

Виклад основного матеріалу.

Підходи до формування територіальних структур характеризуються своєю різноманітністю, деякі 3 них носять лише описовий характер, але більшість методів спираються на математичні та статистичні інструменти.

Для територіального планування регіону доцільно застосовувати моделі прогнозування просторової структури регіону, імітаційні моделі пошуку компромісів інтересів, поведінкові моделі генерування гіпотез розвитку регіону в залежності від змін зовнішнього середовища (мережі Петрі). За допомогою вказаних методів стає можливим обрати оптимальні варіанти зміни виробничої i просторової структури господарства регіону (планувального каркаса території), що відповідає цілям узгодженої взаємодії держави, великого бізнесу і регіону [4].

Крім цього для формування оптимальної територіальної структури господарювання використовуються методи лінійного програмування шляхом співставлення критеріїв фінансової ефективності діяльності ОТГ, які існують в Україні сьогодні [5].

Також можливо використання наукового підходу оптимізації фінансового потенціалу територіальних громад, що базується на основах економікоматематичного моделювання та векторної оптимізації. Побудову математичної моделі можна здійснити за допомогою методу пріоритетів та спеціального симплексметоду, а потім дослідити взаємозв'язки між певними елементами, що належать до складових фінансового потенціалу територіальної структури, використовуючи кореляційний аналіз. Застосування відповідних підходів може бути представлено у вигляді алгоритму, який складається 3 цілого комплексу етапів, послідовне виконання яких сприяє отриманню оптимальних значень об'єктивних і суб'єктивних можливостей, що можуть бути залучені та використані територіальними органами місцевого самоврядування [6].

В останні часи набуває розповсюдженості теоретико-графове моделювання для ефективного управління діяльністю територіальної громади. Методи економіко-математичного та теоретикографового моделювання можуть бути ефективно застосовані для вирішення проблем адміністративно-територіальної реформи [7].

Територіальну економічну кластеризацію (класифікацію) регіонів також можна здійснити, використовуючи карти-ознаки Кохонена. Для того щоб отримати якісну кластеризацию і вибрати оптимальне розбиття карти на кластери алгоритм кластеризації має ряд настроювальних параметрів: число кластерів, мінімальна кількість елементів в кластері, поріг чутливості кластеризації, ступінь диференціації кластерів. Варіюючи значеннями параметрів настройки, отримуємо різне розбиття на кластери. Для вибору оптимального розбиття використовуються такі критерії якості кластеризації, як невелика кількість кластерів (як правило, 3 до 12), сильна диференціація кластерів, стабільність кластеризації (при невеликих змінах бази даних структура карти принципово не змінюється) [8].

Доцільно зауважити, що в останні часи в процесі формування i оптимізації територіальних структур особливого значення набувають методи кластерного аналізу. Завдання кластерного аналізу полягає в тому, щоб на підставі даних, що містяться у великій кількості $\mathrm{X}$, розбити безліч об'єктів $\mathrm{G}$ на $\mathrm{m}$ (m - ціле) кластерів (підмножин) Q1, Q2, .., Qm так, щоб кожен об'єкт $\mathrm{Gj}$ належав одній i тільки одній підмножині розбиття і щоб об'єкти, що належать одному і тому ж кластеру, були подібними, в той час як об'єкти, що 
належать різним кластерам, були різнорідними [9].

Кластерний аналіз дозволяє розглядати досить великий обсяг інформації i різко скорочувати, стискати великі масиви соціально-економічної інформації, робити їх компактними і наочними. Кластерний аналіз має важливе значення для застосування до сукупності часових рядів, що характеризують економічний розвиток. Тут можна виділяти періоди, коли значення відповідних показників були досить близькими, а також визначати групи часових рядів, динаміка яких $є$ найбільш схожою [10]. Як i будь-який інший метод, кластерний аналіз має певні недоліки i обмеження. Зокрема, склад i кількість кластерів залежить від обраних критеріїв розбиття. При зведенні вихідного масиву даних до більш компактного вигляду можуть виникати певні спотворення, а також можуть губитися індивідуальні риси окремих об'єктів за рахунок заміни їх характеристиками узагальнених значень параметрів кластеру. При проведенні класифікації об'єктів дуже часто ігнорується можливість відсутності в даній сукупності будь-яких значень кластерів. Значна перевага кластерного аналізу в тому, що він дозволяє виробляти розбивку об'єктів не по одному параметру, а по цілому набору ознак. Крім того, кластерний аналіз на відміну від більшості математикостатистичних методів не накладає ніяких обмежень на вид розглянутих об'єктів i дозволяє розглядати безліч вихідних даних практично довільної природи. Це має велике значення, наприклад, коли показники мають різноманітний вигляд, що ускладнює застосування традиційних економетричних підходів [11].

Вищенаведена інформація свідчить, що найбільш оптимальним методом для формування територіальної структури регіонального господарства $\epsilon$ саме методи кластерного аналізу, зокрема метод kсередніх.

Алгоритм k-середніх (англ. k-means) належить до одного 3 алгоритмів машинного навчання, що вирішує завдання кластеризації. Цей алгоритм $\epsilon$ неієрархічним, ітераційним методом кластеризації. Як метод кластеризації, отримав велику популярність завдяки своїй простоті, наочності реалізації і досить високій якості роботи. Був винайдений в 50$\mathrm{x}$ роках минулого століття математиком Гуго Штейнгаузом [12] і майже одночасно Стюартом Ллойдом [13]. Особливо популярним став після публікації роботи Маккуїна в 1967 році [14].

Математична модель методу kсередніх:

- відомо набір із $\mathrm{n}$ спостережень $\mathrm{X}=$ $\{x 1, x 2, \ldots, x n\}, x i \in R d, i=1, \ldots, n$;

- k - необхідне число кластерів, $\mathrm{k} \in \mathrm{N}$, $\mathrm{k} \leq \mathrm{n}$.

Необхідно розподілити множину спостережень X на k кластерів S1, S2, ..., Sk:

$-\mathrm{Si} \cap \mathrm{Sj}=\varnothing, \mathrm{i} \neq \mathrm{j}$,

- $\bigcup_{i=1}^{k} S_{i}=X$.

Дія алгоритму така, що він прагне мінімізувати сумарне квадратичне відхилення точок кластерів від центрів цих кластерів:

$$
V=\sum_{i=1}^{k} \sum_{x \in S_{i}}\left(x-\mu_{i}\right)^{2}
$$

де $\mathrm{k}$ - число кластерів, $\mathrm{S}_{\mathrm{i}}$ - отримані кластери, $\mathrm{i}=1,2, \ldots, \mathrm{k}, \mu$ - центри мас усіх векторів х із кластеру $\mathrm{S}_{\mathrm{i}}$.

Алгоритм методу k-середніх схематично зображено на рис. 1. Мета алгоритму полягає в поділі n-ї кількості спостережень на $\mathrm{k}$ кластерів таким чином, щоб кожне спостереження належало тільки до одного кластеру, який розташовано на найменшій відстані від спостереження.

\begin{tabular}{|c|c|c|c|}
\hline $\begin{array}{c}\text { 1. Вибирається } \\
\text { число кластерів k, a } \\
\text { також початкових } \\
\text { точок, які будуть } \\
\text { служити } \\
\text { початковими } \\
\text { центрами кластерів }\end{array}$ & $\begin{array}{l}\text { 2. Для кожного } \\
\text { запису вихідної } \\
\text { вибірки } \\
\text { визначається } \\
\text { найближчий до } \\
\text { неї центр } \\
\text { кластеру }\end{array}$ & $\begin{array}{c}\text { 3. Обчислюю } \\
\text { ться } \\
\text { центроїди - } \\
\text { центри } \\
\text { тяжкості } \\
\text { кластерів }\end{array}$ & $\begin{array}{c}\text { 3. Кордони } \\
\text { кластерів } \\
\text { залишаються } \\
\text { незмінними від } \\
\text { порівняно } 3 \\
\text { попередньою } \\
\text { ітерацією }\end{array}$ \\
\hline
\end{tabular}

Рис.1. Алгоритм методу k-середніх 
Основною ідеєю алгоритму k-середніх $\epsilon$ те, що дані розбиваються в довільному порядку на кластери, після чого ітеративним способом переобчислюється центр мас для кожного кластера, отриманого на попередньому кроці, Кожен центр ваги - це вектор, елементи якого являють собою середні значення ознак, обчислені за всіма записами кластера. Потім центр кластера зміщується в його центр ваги, тобто вектори розбиваються на кластери знову відповідно до того, який 3 нових центрів виявився ближчим по обраній метричній системі.

Алгоритм завершується тоді, коли на якийсь ітерації не відбувається зміни внутрикластерної відстані, тобто на кожній ітерації в кожному кластері буде залишатися один і той же набір записів. Це відбувається за кінцеве число ітерацій, так як кількість можливих розбиттів множин $є$ кінцевим, а на кожному кроці сумарне квадратичне відхилення V зменшується, тому зациклення неможливо [15]

Слід відзначити, що розглянутий метод містить деякі плюси і мінуси.

До основних переваг методу kсередніх відносять:

- простоту реалізації;

- інтуїтивну зрозумілість і прозорість алгоритму.

Поряд цим існують певні недоліки методу k-середніх, зокрема:

- число кластерів треба знати заздалегідь;

залежність результату від

ініціалізації центрів кластерів;

- обчислювальна складність.

Третій недолік вирішується за допомогою за використання ЕОМ.

Отже, за допомогою методу k-середніх доцільно здійснити спробу розбиття населених пунктів окремого району для формування оптимальної територіальної структури регіонального господарювання. У якості основного критерію будуть виступати відстані між населеними пунктами. Доцільність вибору відстані у якості критерію пояснюється тим, що, як правило, мешканці близьких територій мають тісні зв'язки. Крім цього, більшість сільського населення, як правило, користується різними послугами - публічними, освітніми, медичними, культурними тощо - у містах, до яких найближча відстань. Це зумовило вибір міст у якості центрів громади.

В табл. 1 представлена матриця відстаней між населеними пунктами, яка представляє квадратну матрицю типу «об'єкт-об'єкт» n-го порядку (в нашому випадку 16-го) та містить в якості елементів відстані між об'єктами (в нашому випадку населеними пунктами) в метричному просторі.

За допомогою методу k-середніх, здійснимо групування представлених в табл. 1 населених пунктів, що допоможе сформувати оптимальну територіальну структуру, наступним чином:

1. Обираємо в матриці відстаней контрольні точки $\mathrm{e}_{1}, \mathrm{e}_{2}, \mathrm{e}_{3}$. Іншими словами число і центри кластерів. В нашому випадку це будуть точки $\mathrm{N}, \mathrm{O}, \mathrm{P}$ - відповідно міста Покровськ, Мирноград і Селидове.

2. Здійснюємо нульову ітерацію:

1) розраховуємо відстані від точки $А$ до еталонних точок:

- відстань від точки А до контрольної точки $\mathrm{e}_{1}$ :

$d\left(A e_{1}\right)=$

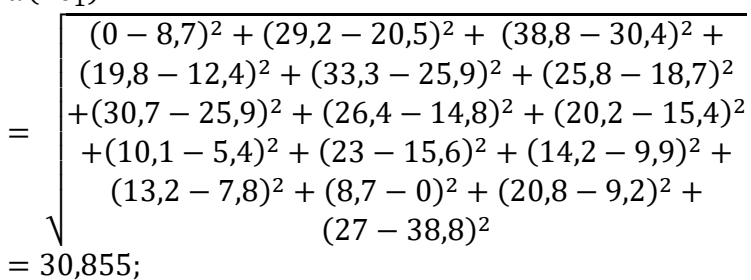

- аналогічно відстань від точки А до контрольної точки $\mathrm{e}_{2}$ :

$$
\mathrm{d}\left(\mathrm{Ae}_{2}\right)=49,843 \text {; }
$$

- відстань від точки А до контрольної точки е :

$$
\mathrm{d}\left(\mathrm{Ae}_{3}\right)=61,543 ;
$$

2) визначаємо мінімальну відстань. В нашому випадку мінімальною $є$ відстань $\mathrm{d}\left(\mathrm{Ae}_{1}\right)$

3) перераховуємо значення для еталонної точки е $\mathrm{e}_{1}$ :

$(0+8,7) / 2=4,35 ;(29,2+20,5) / 2=24,85 ;$

$(38,8+30,4) / 2=34,6 ;(19,8+12,4) / 2=16,1 ;$

$(33,3+25,9) / 2=29,6 ;(25,8+18,7) / 2=22,25 ;$

$(30,7+25,9) / 2=28,3 ;(26,4+14,8) / 2=20,6 ;$

$(20,2+15,4) / 2=17,8 ;(10,1+5,4) / 2=7,75 ;$

$(23+15,6) / 2=19,3 ;(14,2+9,9) / 2=12,05 ;$

$(13,2+7,8) / 2=10,5 ;(8,7+0) / 2=4,35 ;$

$(20,8+9,2) / 2=15 ;(27+19,6) / 2=23,3 ;$

4) кроки 1-3 повторюємо для всіх об'єктів кластеризації - населених пунктів.

5) здійснюємо класифікацію населених пунктів шляхом визначення 
точки, до якої найближче розташований населений пункт. Метод розрахунку аналогічний кроку 1 , проте слід приймати до розрахунку перераховані значення контрольних точок. Отримуємо:

$$
\begin{gathered}
\mathrm{d}\left(\mathrm{Ae}_{1}\right)=27,438 ; \\
\mathrm{d}\left(\mathrm{Ae}_{2}\right)=48 ; \\
\mathrm{d}\left(\mathrm{Ae}_{\mathrm{N} \mathrm{N}}\right)=57,202 .
\end{gathered}
$$

Це означає, що населений пункт А ближче за всіх розташований до еталонної точки $\mathrm{e}_{1}$, тобто відноситься до першого кластеру;

6) крок 5 проводимо для всіх населених пунктів. Таким чином отримуємо першу комбінацію територіальних кластерів.

Таблиця 1

Матриця відстаней між населеними пунктами

\begin{tabular}{|c|c|c|c|c|c|c|c|c|c|c|c|c|c|c|c|c|}
\hline HП* & A & B & C & D & E & F & G & H & I & J & K & L & M & N & O & P \\
\hline A & 0 & 29,2 & 38,8 & 19,8 & 33,3 & 25,8 & 30,7 & 26,4 & 20,2 & 10,1 & 23 & 14,2 & 13,2 & 8,7 & 20,8 & 27 \\
\hline B & 29,2 & 0 & 7,6 & 19 & 10 & 8,4 & 22,3 & 20,7 & 35,5 & 26,3 & 28,5 & 30,5 & 16,9 & 20,5 & 12 & 22 \\
\hline C & 38,8 & 7,6 & 0 & 30,4 & 47,9 & 37,5 & 47,9 & 33,5 & 42,1 & 32,9 & 37,7 & 37,1 & 23,5 & 30,4 & 18,7 & 29,6 \\
\hline D & 19,8 & 19 & 30,4 & 0 & 13,4 & 29 & 20,9 & 25,1 & 23 & 15,8 & 12,6 & 19,9 & 12,5 & 12,4 & 19,5 & 16,6 \\
\hline E & 33,3 & 10 & 47,9 & 13,4 & 0 & 18,5 & 6,3 & 30,7 & 31,9 & 29,2 & 19,5 & 33,4 & 25,6 & 25,9 & 22,1 & 12 \\
\hline F & 25,8 & 8,4 & 37,5 & 29 & 18,5 & 0 & 24,7 & 6,5 & 33,7 & 24,6 & 32,2 & 28,7 & 15,1 & 18,7 & 12,6 & 30,4 \\
\hline G & 30,7 & 22,3 & 47,9 & 20,9 & 6,3 & 24,7 & 0 & 38,6 & 25,6 & 29,3 & 13,2 & 33,4 & 28,3 & 25,9 & 24,9 & 5,8 \\
\hline H & 26,4 & 20,7 & 33,5 & 25,1 & 30,7 & 6,5 & 38,6 & 0 & 29,8 & 20,6 & 28,3 & 24,7 & 11,1 & 14,8 & 8,7 & 32,3 \\
\hline I & 20,2 & 35,5 & 42,1 & 23 & 31,9 & 33,7 & 25,6 & 29,8 & 0 & 11,4 & 14,9 & 12,8 & 19,5 & 15,4 & 24,3 & 21,3 \\
\hline J & 10,1 & 26,3 & 32,9 & 15,8 & 29,2 & 24,6 & 29,3 & 20,6 & 11,4 & 0 & 18,9 & 4,3 & 10,3 & 5,4 & 15,2 & 23 \\
\hline K & 23 & 28,5 & 37,7 & 12,6 & 19,5 & 32,2 & 13,2 & 28,3 & 14,9 & 18,9 & 0 & 23 & 18 & 15,6 & 22,6 & 8,9 \\
\hline L & 14,2 & 30,5 & 37,1 & 19,9 & 33,4 & 28,7 & 33,4 & 24,7 & 12,8 & 4,3 & 23 & 0 & 14,5 & 9,9 & 19,3 & 27,1 \\
\hline M & 13,2 & 16,9 & 23,5 & 12,5 & 25,6 & 15,1 & 28,3 & 11,1 & 19,5 & 10,3 & 18 & 14,5 & 0 & 7,8 & 5,2 & 22 \\
\hline N & 8,7 & 20,5 & 30,4 & 12,4 & 25,9 & 18,7 & 25,9 & 14,8 & 15,4 & 5,4 & 15,6 & 9,9 & 7,8 & 0 & 9,2 & 19,6 \\
\hline O & 20,8 & 12 & 18,7 & 19,5 & 22,1 & 12,6 & 24,9 & 8,7 & 24,3 & 15,2 & 22,6 & 19,3 & 5,2 & 9,2 & 0 & 38,8 \\
\hline P & 27 & 22 & 29,6 & 16,6 & 12 & 30,4 & 5,8 & 32,3 & 21,3 & 23 & 8,9 & 27,1 & 22 & 19,6 & 38,8 & 0 \\
\hline
\end{tabular}

де НП - населені пункти, A - с. Гришино, В - смт. Гродівка, C - с. Іванівка, D - с. Лисівка, E - с. Миколаївка, F -

с. Миролюбівка, G - с. Михайлівка, H - смт. Новоекономічне, I - с. Новотроїцьке, J - с. Перше Травня, K -

с. Петрівське, L - с. Піщане, $\mathrm{M}$ - с. Рівне, $\mathrm{N}$ - м. Покровськ, $\mathrm{O}-$ м. Мирноград, $\mathrm{P}-$ м. Селидове

3. Здійснюємо наступні ітерації, повторюючи всі кроки попереднього етапу. Отримуємо нову комбінацію кластерів. У тому випадку, якщо вона відрізняється від попередньої, то процес розбиття продовжується. Проводимо ітерації до тих пір, поки межі кластерів не стануть незмінними. В нашому випадку рішення отримано вже після другої ітерації. Комбінації територіальних кластерів, отримані за результатами $\mathrm{k}$-аналізу, представлені у табл. 2.

\begin{tabular}{|c|c|c|}
\hline \multicolumn{3}{|c|}{ Ітерація 0} \\
\hline Кластер $1\left(\mathrm{e}_{1}\right)$ & Кластер $2\left(\mathrm{e}_{2}\right)$ & Кластер $3\left(\mathrm{e}_{3}\right)$ \\
\hline ADIJLMN & BCFHO & EGKP \\
\hline \multicolumn{3}{|c|}{ Ітерація 1} \\
\hline Кластер $1\left(\mathrm{e}_{1}\right)$ & Кластер 2 ( (е 2$)$ & Кластер 3 (е $\left.\mathrm{e}_{3}\right)$ \\
\hline AIJLMN & BCFHO & DEGKP \\
\hline \multicolumn{3}{|c|}{ Ітерація 2} \\
\hline Кластер $1\left(\mathrm{e}_{1}\right)$ & Кластер 2 (е 2$)$ & Кластер 3 (ез) \\
\hline AIJLMN & BCFHO & DEGKP \\
\hline ОТГ 1 (м. Покровськ) & ОТГ 2 (м. Мирноград) & ОТГ 3 (м. Селидове) \\
\hline $\begin{array}{c}\text { Гришино, Новотроїцьке, Перше } \\
\text { Травня, Піщане, Рівне }\end{array}$ & $\begin{array}{l}\text { Гродівка, Іванівка, Миролюбівка, } \\
\text { Новоекономічне }\end{array}$ & $\begin{array}{l}\text { Лисівка, Миколаївка, Михайлівка, } \\
\text { Петрівське }\end{array}$ \\
\hline
\end{tabular}

Таблиця 2

Комбінації територіальних кластерів за результатами k-аналізу 
Таким чином, сформовано нову територіальну структуру Покровського району, що складається 3 трьох кластерів 3 центрами у м. Покровськ, м. Мирноград і м. Селидове. В кожний кластер входить оптимальний за критерієм відстані набір територіальних об'єктів.

\section{Обговорення результатів}

На основі використання кластерного аналізу, зокрема методу k-середніх, було проведено групування населених пунктів Покровського району за критерієм відстані (табл. 2). В результаті отримали три групи територіальних кластерів: до складу першого кластеру з центром в м. Покровськ увійшли Гришино, Новотроїцьке, Перше Травня, Піщане, Рівне; другий кластер 3 центром у м. Мирноград включив в себе Гродівку, Іванівку, Миролюбівку, Новоекономічне; третій кластер 3 центром у м. Селидове включив Лисівку, Миколаївку, Михайлівку, Петрівське.

Очевидно, що використаний критерій кластерного аналізу - відстань між населеними пунктами не враховує фінансові можливості майбутніх територіальних об'єднань. При цьому можна впевнено стверджувати, що за допомогою критерію відстані здійснюється спроба узгодити інтереси членів громади. Це пов'язано 3 прискоренням доступу до публічних, отриманням більш якісних освітніх, медичних та інших послуг. Скорочення відстані між окремим населеним пунктом і центром громади відкриває необмежені можливості до розвитку сільського населення. Останнє буде відбуватися при справедливому розподілі коштів територіальної громади між міським та сільським населенням. Вказані механізми потребують підтримки з боку держави.

Використання методичного підходу, заснованому на кластерному аналізі, дозволяе обгрунтувати доцільність створення тієї чи іншої громади для місцевого населення без поглиблення у складні фінансово-економічні розрахунки. Це призведе до прискорення процесу реалізації територіальної реформи, внаслідок чого матимемо оптимальну територіальну структуру регіонального господарювання. Вищесказане в черговий раз наголошує на унікальності запропонованого методичного підходу.

\section{Висновок}

Застосування запропонованого методичного підходу до формування територіальної структури регіонального господарювання, дозволить прийняти обгрунтовані рішення щодо групування територіальних об'єктів в об'єднані територіальні громади. Звісно, що, окрім критерію відстані між населеними пунктами, при об'єднанні територіальних громад слід враховувати багато інших критеріїв, зокрема фінансової спроможності потенційних територіальних об'єднань. Вищесказане ще раз підкреслює, що досліджуваний процес потребує застосування багатьох підходів для визначення різних комбінацій територіальної структури господарювання. Тільки в такому випадку представляється можливим вибір найбільш оптимальної комбінації територіальної структури. Також слід вказати на той факт, що головна проблема полягає не в об'єднанні територій, а в подальшому співіснуванні, спроможності забезпечити достойний рівень життя для всіх без винятку членів громади. Вже зараз мають місце приклади фінансової неспроможності окремих новостворених територіальних громад, як наслідок, процес об'єднання не спростило життя пересічному громадянину, а навпаки. Таким чином, питання потребує ще більш глибокого дослідження.

Практичне значення запропонованого методичного підходу полягає у створенні оптимальних передумов 3 формування територіальної структури регіонального господарювання та гармонізації інтересів всіх зацікавлених сторін.

\section{Список літератури}

1. Про затвердження перспективного плану формування територій громад Донецької області: Розпорядження КМУ від 8.09.2015 p. №1029-p. Дата оновлення: 19.06.2019.

URL: https://zakon.rada.gov.ua/laws/show/1029-2015$\% \mathrm{D} 1 \% 80$ (дата звернення 21.01.2020).

2. Офіційний сайт України «Децентралізація». URL: https://www.minregion.gov.ua/ (дата звернення 25.01.2020).

3. Офіційний сайт Міністерства розвитку громад i територій. URL: 
https://decentralization.gov.ua/ (дата звернення 25.01.2020).

4. Суспицын С.А. Оптимизация территориальных систем. Новосибирск: ИЭОПП СО РАН, 2010. 632 c.

5. Хомюк Н.Л. Формування оптимальної структури об'єднаних територіальних громад Волинської області. Інфраструктура ринку. 2019. Вип. 36. С. 314-319.

6. Тимошенко О.В. Оптимізація фінансового потенціалу територіальних громад. Агросвіт. 2016. №6. С. 12-18.

7. Савенко Р.Г., Скрильник I.I. Застосування теорії графів для оптимального управління територіальною громадою. Збірник наукових праць IX Міжнародної науковопрактичної конференції «Проблеми ци перспективи розвитку академічної та університетської науки», 7-9 грудня 2016 року. Полтава: ПолтНТУ, 2016. С. 69-75.

8. Кутьин В.М. Территориальная экономическая кластеризация (классификация) регионов России: социальногеоэкономический аспект. Безопасность Евразии. 2003. №1. C. 525-536.

9. Мандель И.Д. Кластерный анализ. Москва: Финансы и статистика, 1988. 176 с.

10. Дюран Б., Оделл П. Кластерный анализ. Москва: Статистика, 1977. 128 с.

11. Олдендерфер М.С., Блэшфилд Р.К. Кластерный анализ. Факторный, дискриминантный и кластерный анализ. Москва: Финансы и статистика, 1989. 215 с.

12. Steinhaus H. Sur la division des corps materiels en parties. Bull. Acad. Polon. Sci., 1956. C1. III vol IV. P. 801-804.

13. Lloyd S. Least square quantization in PCM's. Bell Telephone Laboratories Paper. 1957.

14. MacQueen J. Some methods for classification and analysis of multivariate observations. In Proc. 5th Berkeley Symp. on Math. Statistics and Probability, 1967. P. 281-297.

15. Mirkes E.M. K-means and K-medoids applet. University of Leicester, 2011. URL: http://www.math.le.ac.uk/people/ag153/homepage /KmeansKmedoids/Kmeans_Kmedoids.html (дата звернення 15.01.2020).

\section{References}

1. Pro zatverdzhennya perspektyvnoho planu formuvannya terytoriy hromad Donets'koyi oblasti: Rozporyadzhennya KMU vid 8.09.2015 r. №1029-r. Data onovlennya: 19.06.2019.

URL: https://zakon.rada.gov.ua/laws/show/10292015-\%D1\%80.

2. Ofitsiynyy sayt Ukrayiny «Detsentralizatsiya». URL: https://www.minregion.gov.ua/

3. Ofitsiynyy sayt Ministerstva rozvytku hromad i terytoriy. URL: https://decentralization.gov.ua/.

4. Suspitsyn, S.A. (2010), "Optimization of territorial systems" ["Optimizatsiya territorial'nykh sistem"], Novosibirsk: IEOPP SO RAN, 632 p.

5. Khomyuk, N.L. (2019), "Formation of the optimal structure of the united territorial communities of the Volyn region" ["Formuvannya optymal'noyi struktury ob"yednanykh terytorial'nykh hromad Volyns'koyi oblasti"], Market infrastructure [Infrastruktura rynku], Vyp. 36, pp. 314-319.

6. Tymoshenko O.V. (2016), "Optimization of financial potential of local communities" ["Optymizatsiya finansovoho potentsialu terytorial'nykh hromad"], Agroworld [Ahrosvit], №6, pp. 12-18.

7. Savenko R.H., Skryl'nyk I.I. (2016), "Zastosuvannya teoriyi hrafiv dlya optymal'noho upravlinnya terytorial'noyu hromadoyu" ["Application of graph theory for optimal management of the territorial community"], Proceedings of the IX International Scientific and Practical Conference "Problems and Prospects for the Development of Academic and University Science" [Zbirnyk naukovykh prats' IX Mizhnarodnoyi naukovo-praktychnoyi konferentsiyi «Problemy y perspektyvy rozvytku akademichnoyi ta universytet $\cdot \mathrm{s}^{\prime} \mathrm{koyi}$ nauky»], 7-9 hrudnya 2016 roku, Poltava: PoltNTU, pp. 69-75.

8. Kut'in V.M. (2003), "Territorial economic clustering (classification) of Russian regions: socio-geo-economic aspect" ["Territorial'naya ekonomicheskaya klasterizatsiya (klassifikatsiya) regionov Rossii: sotsial'nogeoekonomicheskiy aspekt"], The security of Eurasia The security of Eurasia [Bezopasnost' Yevrazii], №1, pp. 525-536.

9. Mandel' I.D. (1988), Cluster analysis [Klasternyy analiz], Moskva: Finansy i statistika, $176 \mathrm{p}$.

10. Dyuran B., Odell P. (1977), Cluster analysis [Klasternyy analiz], Moskva: Statistika, 128 p.

11. Aldenderfer M.S., Blashfield R.K. (1989), Cluster analysis. Factor, discriminant 
and cluster analysis [Cluster analysis. Factor, discriminant and cluster analysis], Moscow: Finance and Statistics, $215 \mathrm{p}$.

12. Steinhaus H. (1956), Sur la division des corps materiels en parties. Bull. Acad. Polon. Sci., C1, III vol IV, P. 801-804.

13. Lloyd S. (1957), Least square quantization in PCM's. Bell Telephone Laboratories Paper.
14. MacQueen J. (1967), Some methods for classification and analysis of multivariate observations. In Proc. 5th Berkeley Symp. on Math. Statistics and Probability, pp. 281-297.

15. Mirkes E.M. (2011) K-means and Kmedoids applet. University of Leicester. URL: http://www.math.le.ac.uk/people/ag153/homepage /KmeansKmedoids/Kmeans_Kmedoids.html.

\section{МЕТОДИЧНИЙ ПІДХІД ДО ФОРМУВАННЯ ТЕРИТОРІАЛЬНОЇ СТРУКТУРИ РЕГІОНАЛЬНОГО ГОСПОДАРЮВАННЯ}

Виявлено проблеми, пов'язані з впровадженням територіальної реформи. Розглянуто існуючі методичні підходи до формування оптимальної територіальної структури регіонального господарювання. Обгрунтовано доцільність використання кластерного аналізу у побудові оптимальної структури регіонального господарства. Відзначено важність використання відстані між територіальними об'єктами як основного критерію територіальної кластеризації, що відображає інтереси населення, пов'язані 3 більшою доступністю до публічних освітніх, медичних та інших видів послуг.

Виконано групування населених пунктів матриці відстаней методом k-середніх як найбільш популярного різновиду кластерного аналізу, який полягає в розділенні спостережень на окремі кластери за принципом близькості до центру, належить до неієрархічних алгоритмів кластеризації та являє собою ітераційну процедуру.

Мета статті. На основі аналізу існуючих підходів обгрунтувати метод та критерії формування оптимальної територіальної структури регіонального господарювання.

Результати. На основі використання кластерного аналізу, зокрема методу k-середніх, було проведено групування населених пунктів Покровського району за критерієм відстані.

Критерій відстані відповідає інтересам членів громади. Це пов'язано з прискоренням доступу до публічних, отриманням більш якісних освітніх, медичних та інших послуг. Скорочення відстані між окремим населеним пунктом і центром громади відкриває необмежені можливості до розвитку сільського населення.

Використання методичного підходу дозволяє обгрунтувати доцільність створення громади для місцевого населення, не заглиблюючись у складні фінансово-економічні розрахунки.

Висновок. Застосування запропонованого методичного підходу до формування територіальної структури регіонального господарювання дозволить приймати обгрунтовані рішення щодо групування територіальних об’єктів в об’єднані територіальні громади. Практичне значення запропонованого методичного підходу полягає у створенні оптимальних передумов для формування територіальної структури регіонального господарювання та гармонізації інтересів усіх зацікавлених сторін.

Ключові слова: територіальна структура, формування, підходи, кластерний аналіз, критерій територіальної кластеризації, метод k-середніх.

Василишина Любов Миколаївна - старший викладач, ДВНЗ «Донецький національний технічний університет», кафедра управління і фінансово-економічної безпеки, м. Покровськ.

ORCID ID: 0000-0001-8025-7786

e-mail: liubov.vasylyshyna@donntu.edu.ua

\section{METHODICAL APPROACH TO THE FORMATION OF THE TERRITORIAL STRUCTURE OF REGIONAL ECONOMY}

Issues related to the implementation of territorial reform have been identified. Existing methodological approaches to the formation of an optimal territorial structure of regional economy are considered. The expediency of using cluster analysis in building the optimal structure of the regional economy is substantiated. The importance of using the distance between territorial objects as the main criterion of territorial clustering, reflecting the interests of the population related to greater accessibility to public educational, medical and other types of services, was noted.

The grouping of settlements of the matrix of distances by the k-means method was performed as the most popular kind of cluster analysis, which consists of separating observations into separate clusters on the principle of proximity to the center, belongs to non-hierarchical clustering algorithms and is an iterative procedure.

The purpose of the article. Based on the analysis of existing approaches, to substantiate the method and criteria for the formation of an optimal territorial structure of regional economy. 
Results. Based on the use of cluster analysis, in particular the k-means method, the grouping of settlements of the Pokrovsky district by distance criterion was carried out.

The distance criterion matches the interests of community members. This has to do with speeding up access to public services, getting better educational, medical and other services. Reducing the distance between an individual settlement and a community center opens up unlimited opportunities for rural population development.

Using a methodical approach makes it possible to justify the feasibility of creating a community for the local population without delving into complex financial and economic calculations.

Conclusion. The application of the proposed methodical approach to the formation of the territorial structure of regional economy, will allow to make informed decisions on the grouping of territorial objects into integrated territorial communities. The practical significance of the proposed methodical approach is to create optimal prerequisites for the formation of the territorial structure of regional economy and to harmonize the interests of all stakeholders.

Keywords: territorial structure, formation, approaches, cluster analysis, criterion of territorial clustering, k-means method.

Vasylyshyna Liubov - Senior lecturer, Donetsk national technical university, Pokrovsk

\section{МЕТОДИЧЕСКИЙ ПОДХОД К ФОРМИРОВАНИЮ ТЕРИТОРИАЛЬНОЙ СТРУКТУРЫ РЕГИОНАЛЬНОГО ХОЗЯЙСТВОВАНИЯ}

Выявлены проблемы, связанные с внедрением территориальной реформы. Рассмотрены существующие методические подходы к формированию оптимальной территориальной структуры регионального хозяйствования. Обоснована целесообразность использования кластерного анализа в построении оптимальной структуры регионального хозяйствования. Отмечено важность использования расстояния между территориальными объектами как основного критерия территориальной кластеризации, отражающего интересы населения, связанные с большей доступностью к публичным образовательным, медицинским и другим видам услуг.

Выполнена группировка населенных пунктов матрицы расстояний методом $\mathrm{k}$-средних как наиболее популярного вида кластерного анализа, который заключается в разделении наблюдений на отдельные кластеры по принципу близости к центру, относится к неиерархическим алгоритмам кластеризации и представляет собой итерационную процедуру.

Цель статьи. На основе анализа существующих подходов обосновать метод и критерии формирования оптимальной территориальной структуры регионального хозяйствования.

Результаты. На основе использования кластерного анализа, в частности метода k-средних, была осуществлена группировка населенных пунктов Покровского района по критерию расстояния.

Критерий расстояния отвечает интересам членов громады. Это связано с ускорением доступа к публичным услугам, получением более качественных образовательных, медицинских и других услуг. Сокращение расстояния между отдельным населенными пунктами и центром громады открывает неограниченные возможности для развития сельского населения.

Использование методического подхода позволяет обосновать целесообразность создания громады для местного населения, не углубляясь в сложные финансово-экономические расчеты.

Выводы. Применение предложенного методического подхода к формированию территориальной структуры регионального хозяйствования позволит принимать обоснованные решения по группировки территориальных объектов в объединенные территориальные громады. Практическое значение предложенного методического подхода заключается в создании оптимальных условий для формирования территориальной структуры регионального хозяйства и гармонизации интересов всех заинтересованных сторон.

Ключевые слова: территориальная структура, формирование, подходы, кластерный анализ, критерий территориальной кластеризации, метод k-средних.

Василишина Л.Н. - старший преподаватель, Донецкий национальный технический университет, кафедра управления и финансово-экономической безопасности.

ORCID ID: 0000-0001-8025-7786

e-mail: liubov.vasylyshyna@donntu.edu.ua 